\title{
3 Research Square

\section{Inhibition of hemozoin-induced neuroinflammation by medicinal plants used for the treatment of malaria in Southwest Nigeria: implications for cerebral malaria}

Olumayokun Olajide ( $\nabla$ o.a.olajide@hud.ac.uk)

University of Huddersfield https://orcid.org/0000-0002-9254-8334

Victoria Iwuanyanwu

University of Huddersfield

\section{Research Article}

Keywords: Traditional African Medicine, Cerebral malaria, Neuroinflammation, Microglia

Posted Date: November 19th, 2021

DOI: https://doi.org/10.21203/rs.3.rs-1050172/v2

License: (c) (1) This work is licensed under a Creative Commons Attribution 4.0 International License.

Read Full License 


\section{Abstract}

This study aimed to investigate some antimalarial plants for effects on neuroinflammation. Freeze-dried infusions of the plants were investigated for effects on hemozoin-induced neuroinflammation in BV-2 microglia and levels of inflammatory mediators measured. Alstonia boonei (stem bark), Anacardium occidentale (stem bark), Azadiractha indica (leaves), Enantia chlorantha (stem bark), Khaya senegalensis (stem bark), Mangifera indica (stem bark), and Nauclea latifolia (stem bark) produced significant $(p<0.05)$ reduction in TNFa, IL-6, IL-1 $\beta$, MCP-1, RANTES and iNOS/NO production in BV-2 microglia stimulated with a synthetic hemozoin $(400 \mu \mathrm{g} / \mathrm{mL})$. Further experiments showed that pre-treatment with $50 \mu \mathrm{g} / \mathrm{mL}$ of $A$. boonei, $A$. indica, A. occidentale, E. chlorantha and $M$. indica prior to hemozoin stimulation resulted in inhibition of NF-KB activation by $>40 \%$, while $E$. chlorantha, K. senegalensis and $N$. latifolia produced weak activities. Pretreatment with $A$. indica $(50 \mu \mathrm{g} / \mathrm{mL})$ produced the highest inhibition $(58.6 \%)$ of hemozoin-induced increased NLRP3 protein expression, while A. occidentale $(50 \mu \mathrm{g} / \mathrm{mL}), M$. indica $(50 \mu \mathrm{g} / \mathrm{mL})$ and $A$. boonei $(50 \mu \mathrm{g} / \mathrm{mL})$ reduced expression by $54.1 \%, 49.2 \%$ and $47.1 \%$, respectively. Hemozoin-induced increased caspase- 1 activity was reduced by $A$. boonei, $A$. occidentale, $A$. indica, E. chlorantha, and $M$. indica. These results suggest that $A$. boonei, $A$. occidentale, $A$. indica and $M$. indica produced strong inhibition of hemozoin-induced neuroinflammation through mechanisms involving NFKB and NLRP3 inflammasome activation, while moderate activities were produced by $E$. chlorantha, $K$. senegalensis and $N$. latifolia. The outcome of the study provides pharmacological evidence for the potential benefits of the plants as herbal treatments of cerebral malaria symptoms.

\section{Introduction}

According to the World Health Organisation (WHO), malaria was responsible for approximately 409,000 deaths in 2019, with Africa accounting for more than 94\% of global fatalities (WHO 2020). The most severe neurological complication of acute Plasmodium falciparum malaria is cerebral malaria (CM), a condition that is responsible for the majority of deaths in African children. In spite of effective antimalarial treatments and intensive care, cerebral malaria causes $15-20 \%$ mortality, and survivors may develop long-term neurological deficits (Carter et al. 2005; Boivin et al. 2007; John et al. 2008). Consequently, adjunctive treatments are needed to reduce the mortality of this condition.

Several investigations have now established that in malaria, including $\mathrm{CM}$, there is formation of a metabolic product hemozoin as a result of infection of erythrocytes by Plasmodium falciparum. Hemozoin is known to induce inflammation and morphological changes in microvascular endothelium (Medana and Turner 2006; Prato et al. 2011), leading to an increase in blood brain barrier (BBB) permeability, neuroinflammation and neurological sequelae in survivors (Basilico et al. 2003; Tripathi et al. 2009). Similar to these reports, our investigations have revealed that a synthetic form of hemozoin is in fact able to induce neuroinflammation in BV-2 microglia (Velagapudi et al. 2019). Consequently, reducing the CNS effects of hemozoin in CM is a potential adjunctive strategy in reducing the neurological outcomes of the disease. 
Plants have a long history of use Traditional African Medicine (TAM) for treating malaria and its complications such as $\mathrm{CM}$. Some of these plants are potential interventions in treating $\mathrm{CM}$ due to their ability to reduce processes involved in the activation of neuroinflammation in the brain. For instance, Terminalia albida has been shown to improve survival in experimental CM through its anti-inflammatory action (Camara et al. 2019). Similarly, an extract of Azadiractha indica was shown to reduce neuroinflammation and severity of brain oedema in an experimental model of CM (Bedri et al. 2013). Recently, we reported that an extract of Zanthoxylum zanthoxyloides attenuated neuroinflammation induced with synthetic hemozoin in BV-2 microglia (Ogunrinade et al. 2021). These reports are encouraging developments, and suggest that further pharmacological evaluation of plants used in TAM for treating malaria and/or CM is warranted.

In this study, we conducted a survey of plants used in the treatment of malaria and/or CM in southwest Nigeria and evaluated freeze-dried infusions of plants with the highest fidelity levels for effects on the increased production of pro-inflammatory mediators in BV-2 microglia stimulated with a synthetic form of hemozoin $(\mathrm{HZ})$.

\section{Material And Methods}

\section{Materials}

Synthetic hemozoin was purchased from InvivoGen (France) and prepared fresh in sterile distilled water.

\section{Collection of plant samples}

Field surveys were conducted in Agbegi village, Ikire (Southwest Nigeria), lle-lgbon (Southwest Nigeria), Beere/Oje area (Ibadan, Southwest Nigeria), llesa (Southwest Nigeria) and lle-Ife (Southwest Nigeria). Traditional medicine practitioners in these communities were approached and informed of the purpose of the study, including research objectives, methods of data collection, and intention to publish data. Thereafter, semi-structured interviews were conducted to gather information on the use, preparation, application and properties of herbs used for treating symptoms of malaria and/or cerebral malaria were obtained from each traditional medicine practitioner. Healers were asked specifically for herbal preparations used in treating the usual symptoms of malaria (fever, aches, pains), in addition to cerebral malaria specific symptoms such as coma and seizures.

The Fidelity Level (FL) which is the ratio between the number of informants who independently suggested the use of a plant for malaria/cerebral malaria and the total number of informants who mentioned the plant for any use was calculated using the formula: $\mathrm{FL}=$

$\mathrm{Np}$ : is the number of informants that report a use of a plant species to treat malaria and/or cerebral malaria 
$\mathrm{N}$ : the number of informants that used the plants as a medicine to treat any given disease (Friedman et al. 1986).

Plants with FL $>50 \%$ for the treatment of malaria/cerebral malaria symptoms in these surveys were collected and samples authenticated by a botanist in the Herbarium of Forestry Research Institute of Nigeria, Ibadan. Voucher specimens were prepared and numbers assigned.

\section{Preparation of herbal infusions}

Plant samples were air-dried and reduced to powdery forms. Thereafter, infusions were prepared by adding $1 \mathrm{~g}$ of dried, powdered samples to $200 \mathrm{~mL}$ of boiling distilled water and then left to stand at room temperature for $5 \mathrm{~min}$. Subsequently, infusions were filtered and freeze-dried in a Christ Alpha 2-4 LDplus freeze dryer. Known concentrations of freeze-dried plant materials were prepared fresh in sterile distilled water for pharmacological experiments.

\section{Cell culture}

BV-2 mouse microglia cell line (ICLCATL03001) was purchased from Interlab Cell Line Collection (Banca Biologica e Cell Factory, Italy) and cultured in RPMI medium supplemented with $10 \%$ foetal bovine serum.

\section{Cell viability}

Viability of BV-2 cells stimulated with hemozoin in the presence or absence of plant extracts was measured by the MTT assay. Cells were seeded out in a 96-well plate at $5 \times 10^{5} \mathrm{cells} / \mathrm{ml}$ and then treated with 25 and $50 \mu \mathrm{g} / \mathrm{ml}$ of freeze-dried plant infusions for 30 min, followed by stimulation with $\mathrm{HZ}$ (400 $\mu \mathrm{g} / \mathrm{ml})$ for $24 \mathrm{~h}$. Then cell culture medium was removed and replaced with MTT solution $(5 \mathrm{mg} / \mathrm{ml})$, followed by incubation for $4 \mathrm{~h}$. Thereafter, $150 \mu \mathrm{L}$ of MTT solution was removed from each well and replaced with $150 \mu \mathrm{L}$ DMSO. Formazan crystals were dissolved by shaking the plate on a rocker. Absorbance was read in a microplate reader (Infinite M Nano, Tecan) at a wavelength of at $570 \mathrm{~nm}$.

\section{Production of TNFa, IL-6, IL-1 $\beta$, MCP-1, and RANTES}

BV-2 microglia were seeded out in a 24-well plate at $5 \times 10^{5} \mathrm{cells} / \mathrm{ml}$ and treated with 25 and $50 \mu \mathrm{g} / \mathrm{ml}$ of freeze-dried plant infusions for $30 \mathrm{~min}$, followed by stimulation with $\mathrm{HZ}(400 \mu \mathrm{g} / \mathrm{ml})$ for $24 \mathrm{~h}$. At the end of the stimulation period, culture supernatants were collected. Levels of TNFa, IL- 6 , and IL-1 $\beta$ in culture supernatants were measured using mouse ELISA assay kits (Biolegend). Production of CCL2 was evaluated using Invitrogen ${ }^{\text {TM }}$ eBioscience ${ }^{\text {TM }}$ Mouse CCL2 (MCP-1) ELISA Ready-SET-Go! ${ }^{\text {TM }}$ kit (Thermo Scientific), while CCL5 production was measured with Mouse CCL5/RANTES DuoSet ELISA (R and D 
Systems). All ELISA measurements were carried out according to the manufacturer's instructions and absorbance measured at $450 \mathrm{~nm}$ in a Tecan Infinite M Nano microplate reader.

\section{Nitrite production}

BV-2 microglia were seeded out in a 24-well plate at $5 \times 10^{5}$ cells $/ \mathrm{ml}$ and treated with 25 and $50 \mu \mathrm{g} / \mathrm{ml}$ of plant infusions for $30 \mathrm{~min}$, followed by stimulation with $\mathrm{HZ}(400 \mu \mathrm{g} / \mathrm{ml})$ for $24 \mathrm{~h}$. At the end of the stimulation period, culture supernatants were collected, and levels of NO were determined using the Griess assay kit (Promega).

\section{Caspase-Glo ${ }^{\circledR} 1$ inflammasome assay}

The caspase-Glo ${ }^{\circledR} 1$ inflammasome assay (Promega) was used to evaluate the effect of preparations on caspase-1 activity in BV-2 microglia stimulated with hemozoin. BV-2 cells were seeded in 96-well plates and pre-treated with 25 and $50 \mu \mathrm{g} / \mathrm{ml}$ of plant infusions 30 min prior to activation with $\mathrm{HZ}(400 \mu \mathrm{g} / \mathrm{ml})$ for a further $24 \mathrm{~h}$. Activity of caspase- 1 in cells was thereafter measured according to the manufacturer's instructions. Luminescence was read with FLUOstar OPTIM reader (BMG LABTECH).

\section{In cell western assays for iNOS and NLRP3 proteins}

BV-2 microglia were seeded into 96-well plates and treated with 25 and $50 \mu \mathrm{g} / \mathrm{ml}$ of plant infusions and incubated for 30 min prior to stimulation with $\mathrm{HZ}(400 \mu \mathrm{g} / \mathrm{ml})$ for a further $24 \mathrm{~h}$. At the end of each experiment, cells were fixed with $8 \%$ paraformaldehyde solution $(100 \mu \mathrm{L})$ for $15 \mathrm{~min}$., followed by washing with PBS. The cells were then incubated with rabbit anti-iNOS (Abcam) and rabbit anti-NLRP3 (Abcam) antibodies overnight at $4^{\circ} \mathrm{C}$. Thereafter, cells were washed with PBS and incubated with antirabbit HRP secondary antibody for $2 \mathrm{~h}$ at room temperature. Then, $100 \mu \mathrm{L}$ avidin HRP substrate was added to each well and absorbance measured at $450 \mathrm{~nm}$ with a Tecan Infinite M Nano microplate reader. Readings were normalised with Janus Green normalisation stain (Abcam).

\section{NF-kB transcription factor assay}

Effects of plant infusions on DNA binding of NF-kB following stimulation by hemozoin was quantitatively evaluated using the NF-kB transcription factor assay kit (Abcam). Following treatment of BV-2 microglia with 25 and $50 \mu \mathrm{g} / \mathrm{ml}$ of plant infusions for $30 \mathrm{~min}$, the cells were stimulated with $\mathrm{HZ}(400 \mu \mathrm{g} / \mathrm{ml})$ for $60 \mathrm{~min}$. This was followed by preparation of nuclear extracts, which were then used in DNA binding assays according to the manufacturer's instructions. Absorbance was measured at $450 \mathrm{~nm}$ with a Tecan Infinite M Nano microplate reader. 


\section{Phospho-p65 NF-kB and phospho-IkBa ELISAs}

BV-2 microglia cells were seeded out into 6-well plates and treated with 25 and $50 \mu \mathrm{g} / \mathrm{ml}$ of freeze-dried plant infusions and incubated for $30 \mathrm{~min}$ prior to stimulation with $\mathrm{HZ}(400 \mu \mathrm{g} / \mathrm{ml})$ for a further $60 \mathrm{~min}$. At the end of the experiments, plates were washed with PBS, followed by the addition of cell lysis buffer (Cell Signalling Technology). The plate was then incubated on ice for 5 min and cells scraped. Extracts were sonicated and centrifuged at $14,000 \times \mathrm{g}$ at $4^{\circ} \mathrm{C}$ for $10 \mathrm{~min}$. Protein levels of phospho-p65 in the resulting cell lysates were measured using PathScan ${ }^{\circledR}$ phospho-NF-kB p65 (Ser536) sandwich ELISA kit. Absorbance (protein expression) was measured at $450 \mathrm{~nm}$ with a Tecan Infinite M Nano microplate reader.

\section{Statistical analysis}

Data are expressed as mean \pm SEM for at least 3 independent experiments $(n=3)$ and analysed using oneway analysis of variance (ANOVA) with post hoc Dunnett's multiple comparison test. Statistical analysis were conducted using the GraphPad Prism software.

\section{Results}

\section{Ethnopharmacological field surveys}

Ethnopharmacological field surveys conducted in 5 locations within southwest Nigeria revealed that 12 of the plant species mentioned by traditional medicine practitioners had $>50 \%$ fidelity level for treating symptoms of malaria and cerebral malaria (Table 1). Preliminary pharmacological evaluation of 25 and $50 \mu \mathrm{g} / \mathrm{mL}$ of freeze-dried plant infusions showed that Alstonia boonei, Anacardium occidentale, Enantia chlorantha, Khaya senegalensis, Mangifera indica, and Nauclea latifolia produced significant $(p<0.05)$ reduction in the increased production of TNFa in HZ-stimulated BV-2 microglia (Supplementary Data 1). Results of cell viability experiments showed that 25 and $50 \mu \mathrm{g} / \mathrm{mL}$ of freeze-dried infusions did not reduce viability of HZ-stimulated BV-2 microglia (Supplementary Data 2). These plants were then selected for further pharmacological evaluation.

\section{Effects of freeze-dried plant infusions on the production of pro-inflammatory cytokines}

Results in Figure $1 A$ show that in response to stimulation with synthetic hemozoin $(400 \mu \mathrm{g} / \mathrm{mL})$, secretion of TNFa in BV-2 microglia was significantly $(p<0.001)$ increased. However, significant $(p<0.001)$ reduction in TNFa production was observed following pre-treatment with 25 and $50 \mu \mathrm{g} / \mathrm{mL}$ of $A$. boonei, $A$. occidentale, E. chlorantha, K. senegalensis, $M$. indica, and N. latifolia prior to stimulation with HZ. Similar reduction in $\mathrm{HZ}$-induced increased production of IL-6 (Figure 1B) and IL-1 $\beta$ (Figure 1C) were observed 
following pre-treatment of BV-2 microglia with 25 and $50 \mu \mathrm{g} / \mathrm{mL}$ of $A$. boonei, A. occidentale, $E$. chlorantha, K. senegalensis, M. indica, and N. latifolia.

\section{Effects of freeze-dried plant infusions on the production of pro-inflammatory chemokines}

Experiments to determine effects of plants on inflammatory chemokines showed that stimulation of BV-2 microglia with $\mathrm{HZ}(400 \mu \mathrm{g} / \mathrm{mL})$ resulted in significant $(p<0.001)$ elevation in the release of MCP-1 (Figure 2A) and CCL-5/RANTES (Figure 2B). When cells were pre-treated with freeze-dried A. boonei (25 and 50 $\mu \mathrm{g} / \mathrm{mL}$ ), MCP-1 production was reduced by $32.7 \%$ and $44.5 \%$, respectively when compared with $\mathrm{HZ}$ stimulation alone. In the presence of $50 \mu \mathrm{g} / \mathrm{mL}$ of freeze-dried $A$. occidentale, $A$. indica, E. chlorantha, $K$. senegalensis, $M$. indica, and Nauclea latifolia, HZ-induced increased production of MCP-1 was reduced by $47.1 \%, 47.2 \%, 42 \%, 38.6 \%, 48.5 \%$ and $38.9 \%$, respectively (Figure $2 \mathrm{~A}$ ). Similarly, pre-treatment of HZstimulated BV-2 microglia with $50 \mu \mathrm{g} / \mathrm{mL}$ of freeze-dried $A$. boonei, $A$. occidentale, $A$. indica, E. chlorantha, K. senegalensis, $M$. indica, and Nauclea latifolia resulted in the reduction of RANTES by $54.2 \%, 48.5 \%$, $50.3 \%, 39.2 \%, 40.9 \%, 47.5 \%$, and 38.5 , respectively (Figure $2 \mathrm{~B}$ ).

\section{Freeze-dried plant infusions inhibited iNOS/NO production in hemozoin-stimulated BV-2 microglia}

Further experiments to evaluate effects of freeze-dried plants on $\mathrm{HZ}$-induced increased production of inflammatory mediators in BV-2 microglia revealed marked reduction in NO production by freeze-dried $A$. boonei (43.9\% reduction with $50 \mu \mathrm{g} / \mathrm{mL}), A$. occidentale ( $49.3 \%$ reduction with $50 \mu \mathrm{g} / \mathrm{mL}$ ), $A$. indica ( $41.4 \%$ reduction with $50 \mu \mathrm{g} / \mathrm{mL}$ ), and $M$. indica ( $47.5 \%$ reduction with $50 \mu \mathrm{g} / \mathrm{mL}$ ) (Figure $3 \mathrm{~A})$. A similar trend was observed in results obtained from in cell western experiments to determine effects of freeze-dried plants on $\mathrm{HZ}$-induced increased expression of iNOS protein in BV-2 microglia. As shown in Figure 3B, pre-treatment of BV-2 microglia with $50 \mu \mathrm{g} / \mathrm{mL}$ of $A$. boonei, A. occidentale, A. indica, and $M$. indica resulted in $48.9 \%, 45.8 \%, 53.1 \%$ and $51.2 \%$ reduction in iNOS protein levels, respectively. Modest reductions in $\mathrm{HZ}$-induced elevated NO production and iNOS protein expression were achieved with $E$. chlorantha. K. senegalensis and N. latifolia (Figures 3A \& 3B).

\section{Anti-inflammatory effects of freeze-dried plants infusions were mediated through mechanisms involving NF-kB activation}

Encouraged by results showing varying degrees of anti-inflammatory activity by the plants, we then investigated their effects on $\mathrm{HZ}$-induced activation of the NF-kB transcription factor. Interestingly, we observed that incubating BV-2 microglia with $50 \mu \mathrm{g} / \mathrm{mL}$ of $A$. boonei, A. indica, A. occidentale, $E$. 
chlorantha and $M$. indica prior to stimulation with $\mathrm{HZ}(400 \mu \mathrm{g} / \mathrm{mL})$ produced $>40 \%$ reduction in the levels of phospho-p65 protein measured using ELISA (Figure 4A).

We further used a transcription factor assay to evaluate the impact of pre-treatment with freeze-dried plants on nuclear DNA binding of NF-kB following stimulation of BV-2 microglia with $\mathrm{HZ}(400 \mu \mathrm{g} / \mathrm{mL})$. Results in Figure 4B shows that $50 \mu \mathrm{g} / \mathrm{mL}$ of freeze-dried $A$. boonei, $A$. occidentale, A. indica, $M$. indica and $N$. latifolia inhibited $\mathrm{HZ}$-induced increased DNA binding by $50.5 \%, 48.8 \%, 53.4 \%, 49.6 \%$, and $43.4 \%$, respectively (Figure 4B).

\section{Freeze-dried plant infusions reduced NLRP3 inflammasome protein and caspase-1 activity in hemozoin-stimulated BV-2 microglia}

Hemozoin has been reported to induce the release of IL-1 $1 \beta$ through mechanisms involving activation of NLRP3 inflammasome/caspase-1 activity in BV-2 microglia [9]. Following results showing inhibition of $\mathrm{HZ}$-induced increased IL-1 $\beta$ production by freeze-dried plants, we investigated their effects of protein levels of NLRP3 inflammasome, as well as caspase- 1 activity in HZ-stimulated BV-2 microglia. Results in Figure 5A show that increased protein expression of NLRP3 inflammasome following stimulation with $\mathrm{HZ}$ $(400 \mu \mathrm{g} / \mathrm{mL})$ was significantly reduced $(p<0.05)$ in the presence of 25 and $50 \mu \mathrm{g} / \mathrm{mL}$ of all freeze-dried plant preparations. Pre-treatment with $A$. indica $(50 \mu \mathrm{g} / \mathrm{mL})$ produced the highest inhibition $(58.6 \%)$, while A. occidentale $(50 \mu \mathrm{g} / \mathrm{mL}), M$. indica $(50 \mu \mathrm{g} / \mathrm{mL})$ and $A$. boonei $(50 \mu \mathrm{g} / \mathrm{mL})$ inhibited NLRP3 expression by $54.1 \%, 49.2 \%$ and $47.1 \%$, respectively.

Interestingly, $\mathrm{HZ}$-induced increased BV-2 microglia caspase-1 activity was significantly reduced $(\mathrm{p}<0.05)$ by both 25 and $50 \mu \mathrm{g} / \mathrm{mL}$ of $A$. boonei, $A$. occidentale, $A$. indica, E. chlorantha, and $M$. indica. However, significant $(p<0.05)$ reduction in activity was achieved with $50 \mu \mathrm{g} / \mathrm{mL}$ of $K$. senegalensis, while $N$. latifolia did not produce significant reduction in activity at both concentrations investigated (Figure 5B).

\section{Discussion}

Some medicinal plants used in the treatment of symptoms of malaria have been proven to provide symptomatic relief because of their anti-inflammatory activity in reducing levels of mediators which contribute to fever, aches and pains. Similarly, it has been suggested that some of these plants may be valuable in the adjunctive treatment of neurological sequelae of cerebral malaria due to their antiinflammatory activity.

Using the Fidelity Level (FL) as a measure of consensus on the use of plants for treating symptoms of malaria and/or cerebral malaria, Ageratum conyzoides (leaves), Alstonia boonei (stem bark), Anacardium occidentale (stem bark), Azadiractha indica (leaves), Chromolaena odorata (whole plant), Enantia chlorantha (stem bark), Khaya senegalensis (stem bark), Mangifera indica (stem bark), Nauclea 
latifolia (stem bark), Psidium guajava (leaves), Tithonia diversifolia (leaves) and Vernonia amygdalina (leaves) were reported to score an FL greater than 50\%. Interestingly, studies have demonstrated antimalarial activities of some of these plants in vitro and in vivo (Awe et al. 1998; Benoit-Vical et al. 1998; Elufioye and Agbedahunsi 2004; Udeinya et al. 2006; Nour et al. 2010; Owuor et al. 2012; Olanlokun et al. 2012; Kemgne et al. 2012; Ndjonka et al. 2012; Adepiti et al. 2014; Ezenyi et al. 2014; Bihonegn et al. 2019).

In preliminary pharmacological investigations on freeze-dried infusions of the plants, Alstonia boonei, Anacardium occidentale, Azadiractha indica, Enantia chlorantha, Khaya senegalensis, Mangifera indica, and Nauclea latifolia produced significant reduction of increased production of TNFa in BV-2 microglia stimulated with a synthetic hemozoin. Further investigations revealed that these plants reduced the production of the pro-inflammatory cytokines IL-6, IL-1 $\beta$ as well as chemokines MCP-1 and CCL5/RANTES in BV-2 microglia stimulated with hemozoin.

The effects of these plants in reducing the production of pro-inflammatory cytokines and chemokines is remarkable considering the roles of these mediators in the pathogenesis of cerebral malaria. Increased levels of TNFa, IL- 6 and IL-1 $\beta$ have been reported to be associated with the pathogenesis of cerebral malaria (Idro et al. 2010). Also, studies have shown that chemokines such as MCP-1 and RANTES/CCL5 contribute to the pathogenesis of this malaria complication (Pacher et al. 2007). Furthermore, we have shown that a synthetic form of the malaria metabolic product hemozoin increased pro-inflammatory cytokine production in BV-2 microglia (Velagapudi et al. 2019), confirming their roles in CNS immune responses to malaria infection.

Excessive production of nitric oxide (NO) by brain microglia during neuroinflammation has been linked to damage to adjacent neurons. In cerebral malaria, iNOS-mediated NO production has been postulated to be cytotoxic to neurons through different mechanisms (Pacher et al. 2007). Results from this study show strong inhibition of iNOS-mediated increased production of NO by freeze-dried infusions of Alstonia boonei, Anacardium occidentale, Azadiractha indica, and Mangifera indica in hemozoin-stimulated BV-2 microglia, while Enantia chlorantha, Khaya senegalensis and Nauclea latifolia produced modest effects. These results further demonstrate the potential benefits of these plants as herbal remedies in the treatment of cerebral malaria, at least due to their ability to reduce inflammatory responses in the brain. Previous studies have reported anti-inflammatory effects for Alstonia boonei (Olajide et al. 2000), Anacardium occidentale (Olajide et al. 2004), Azadiractha indica (Okpanyi and Ezeukwu 1981), and Mangifera indica (Ojewole 2005), which may explain their strong anti-inflammatory activity against hemozoin-induced neuroinflammation observed in this study.

Activation of the NF-kB is known to regulate the production of pro-inflammatory cytokines, chemokines and mediators such nitric oxide. Activation of this transcription factor has also been implicated in the pathology of cerebral malaria (Kumar et al. 2003; Tripathi et al. 2006; Tripathi et al. 2009), and has been shown to be one of the critical mechanisms involved in hemozoin-induced neuroinflammation (Velagapudi et al. 2019). These links, coupled with our results showing marked reduction in the 
production of inflammatory mediators by plants under investigation encouraged us to investigate their effects on the activation of NF-kB following stimulation of BV-2 microglia with synthetic hemozoin. Consistent with their effects on TNFa, IL-6, IL-1ß, MCP-1, RANTES/CCL5, and INOS/NO, freeze-dried infusions of Alstonia boonei, Anacardium occidentale, Azadiractha indica, and Mangifera indica produced significant inhibition of hemozoin-induced increased phosphorylation of NF-kB p65 sub-unit and its binding to the DNA in the nucleus, an outcome suggesting that the plants may be reducing inflammation through mechanisms involving NF-kB activation. Studies have previously shown that an extract of Anacardium occidentale inhibited neuroinflammation in lipopolysaccharide-stimulated BV-2 microglia, through mechanisms involving NF-kB (Olajide et al. 2013). Similarly, modulation of NF-kB activation has been suggested as a possible mechanism for the anti-inflammatory activity of Azadiractha indica (Pooladanda et al. 2019) and Mangifera indica (Garrido et al. 2005).

There have been suggestions in scientific literature that malaria hemozoin activates NLRP3 inflammasome/caspase-1 pathway to release IL-1 $\beta$ (Dostert et al. 2009; Shio et al. 2009; Velagapudi et al. 2019; Ogunrinade et al. 2021). In this study, we have demonstrated significant inhibition of hemozoininduced NLRP3 protein expression by all plants investigated. However, Khaya senegalensis and Nauclea latifolia did not have effect on hemozoin-induced caspase-1 activity.

Results of this study have shown that freeze-dried samples of Alstonia boonei, Anacardium occidentale, Azadiractha indica and Mangifera indica produced strong activity in reducing synthetic hemozoininduced neuroinflammation in BV-2 microglia through mechanisms involving NF-kB and NLRP3 inflammasome activation. Moderate activities have been shown by Enantia chlorantha, Khaya senegalensis and Nauclea latifolia. The outcome of this study provides pharmacological evidence for the use of these plants in Traditional African Medicine for treating symptoms and complications of malaria, including cerebral malaria. It is not yet clear how these plants may be acting in vivo to overcome the blood-brain barrier, and should be investigated in human intervention studies involving patients presenting with malaria and/or cerebral malaria.

\section{Declarations}

\section{Acknowledgement}

This work was supported by the Ekhagastiftelsen [grant number 2019-72].

\section{Data Availability}

All data used during this study are available from the corresponding author.

\section{Conflicts of Interest}

The authors declare that they have no conflicts of interest. 


\section{References}

Adepiti AO, Elujoba AA, Bolaji OO (2014) In vivo antimalarial evaluation of MAMA decoction on Plasmodium berghei in mice. Parasitol Res. 113: 505-511. https://doi.org/10.1007/s00436-013-3680-0

Awe SO, Olajide OA, Oladiran OO, Makinde JM (1998) Antiplasmodial and antipyretic screening of Mangifera indica extract. Phytother Res. 12: 437-438.

Basilico N, Tognazioli C, Picot S, Ravagnani F, Taramelli D (2003) Synergistic and antagonistic interactions between haemozoin and bacterial endotoxin on human and mouse macrophages. Parassitologia 45: 135-140.

Bedri S, Khalil EA, Khalid SA, Alzohairy MA, Mohieldein A, Aldebasi YH, Seke Etet PF, Farahna M (2013) Azadirachta indica ethanolic extract protects neurons from apoptosis and mitigates brain swelling in experimental cerebral malaria. Malar J. 12: 298. https://doi.org/10.1186/1475-2875-12-298

Benoit-Vical F, Valentin A, Cournac V, Pélissier Y, Mallié M, Bastide JM (1998) In vitro antiplasmodial activity of stem and root extracts of Nauclea latifolia S.M. (Rubiaceae). J Ethnopharmacol. 61: 173178. https://doi.org/10.1016/s0378-8741(98)00036-1

Bihonegn T, Giday M, Yimer G, Animut A, Sisay M (2019) Antimalarial activity of hydromethanolic extract and its solvent fractions of Vernonia amygdalina leaves in mice infected with Plasmodium berghei. SAGE Open Med. 7: 2050312119849766. https://doi.org/10.1177/2050312119849766

Boivin MJ, Bangirana P, Byarugaba J, Opoka RO, Idro R, Jurek AM, John CC (2007) Cognitive impairment after cerebral malaria in children: a prospective study. Pediatrics 119: e360e366. https://doi.org/10.1542/peds.2006-2027

Camara A, Haddad M, Reybier K, Traoré MS, Baldé MA, Royo J, Baldé AO, Batigne P, Haidara M, Baldé ES, Coste A, Baldé AM, Aubouy A (2019) Terminalia albida treatment improves survival in experimental cerebral malaria through reactive oxygen species scavenging and anti-inflammatory properties. Malar J. 18: 431. https://doi.org/10.1186/s12936-019-3071-9

Carter JA, Mung'ala-Odera V, Neville BG, Murira G, Mturi N, Musumba C, Newton CR (2005) Persistent neurocognitive impairments associated with severe falciparum malaria in Kenyan children. $J$ Neurol Neurosurg Psychiatry. 76: 476-481. https://doi.org/10.1136/jnnp.2004.043893

Dostert C, Guarda G, Romero JF, Menu P, Gross O, Tardivel A, Suva ML, Stehle JC, Kopf M, Stamenkovic I, Corradin G, Tschopp J (2009) Malarial hemozoin is a Nalp3 inflammasome activating danger signal. PLoS One. 4: e6510. https://doi.org/10.1371/journal.pone.0006510

Elufioye TO, Agbedahunsi JM (2004) Antimalarial activities of Tithonia diversifolia (Asteraceae) and Crossopteryx febrifuga (Rubiaceae) on mice in vivo. J Ethnopharmacol. 93: 167-

171. https://doi.org/10.1016/j.jep.2004.01.009

Page $11 / 18$ 
Ezenyi IC, Salawu OA, Kulkarni R, Emeje M (2014) Antiplasmodial activity-aided isolation and identification of quercetin-4'-methyl ether in Chromolaena odorata leaf fraction with high activity against chloroquine-resistant Plasmodium falciparum. Parasitol Res. 113: 44154422. https://doi.org/10.1007/s00436-014-4119-y

Friedman J, Yaniv Z, Dafni A, Palewitch D (1986) A preliminary classification of the healing potential of medicinal plants, based on a rational analysis of an ethnopharmacological field survey among Bedouins in the Negev desert, Israel. J Ethnopharmacol. 16: 275-287. https://doi.org/10.1016/03788741(86)90094-2

Garrido G, Blanco-Molina M, Sancho R, Macho A, Delgado R, Muñoz E (2005) An aqueous stem bark extract of Mangifera indica (Vimang) inhibits T cell proliferation and TNF-induced activation of nuclear transcription factor NF-kappaB. Phytother Res.19: 211-215. https://doi.org/10.1002/ptr.1656

Idro R, Marsh K, John CC, Newton CR (2010) Cerebral malaria: mechanisms of brain injury and strategies for improved neurocognitive outcome. Pediatr Res. 68: 267-

274. https://doi.org/10.1203/PDR.0b013e3181eee738

John CC, Bangirana P, Byarugaba J, Opoka RO, Idro R, Jurek AM, Wu B, Boivin MJ (2008) Cerebral malaria in children is associated with long-term cognitive impairment. Pediatrics 122: e92e99. https://doi.org/10.1542/peds.2007-3709

Kemgne EA, Mbacham WF, Boyom FF, Zollo PH, Tsamo E, Rosenthal PJ (2012) In vitro sensitivity of Plasmodium falciparum field isolates to extracts from Cameroonian Annonaceae plants. Parasitol Res. 110: 109-117. https://doi.org/10.1007/s00436-011-2456-7

Kumar KA, Rajgopal Y, Pillai U, Babu PP (2003) Activation of nuclear transcription factor-kappa B is associated with the induction of inhibitory kappa $\mathrm{B}$ kinase-beta and involves differential activation of protein kinase $\mathrm{C}$ and protein tyrosine kinases during fatal murine cerebral malaria. Neurosci Lett. 340: 139-142. https://doi.org/10.1016/s0304-3940(03)00107-1

Medana IM, Turner GD (2006) Human cerebral malaria and the blood-brain barrier. Int J Parasitol. 36: 555-568. https://doi.org/10.1016/j.ijpara.2006.02.004

Ndjonka D, Bergmann B, Agyare C, Zimbres FM, Lüersen K, Hensel A, Wrenger C, Liebau E (2012) In vitro activity of extracts and isolated polyphenols from West African medicinal plants against Plasmodium falciparum. Parasitol Res. 111: 827-834. https://doi.org/10.1007/s00436-012-2905-y

Nour AM, Khalid SA, Kaiser M, Brun R, Abdalla WE, Schmidt TJ (2010) The antiprotozoal activity of methylated flavonoids from Ageratum conyzoides L. J Ethnopharmacol. 129: 127130. https://doi.org/10.1016/j.jep.2010.02.015 
Ogunrinade FA, Guetchueng ST, Katola FO, Aderogba MA, Akande IS, Sarker SD, Olajide OA (2021)

Zanthoxylum zanthoxyloides inhibits lipopolysaccharide- and synthetic hemozoin-induced neuroinflammation in BV-2 microglia: roles of NF-kB transcription factor and NLRP3 inflammasome activation. J Pharm Pharmacol. 73: 118-134. https://doi.org/10.1093/jpp/rgaa019

Ojewole JA (2005) Antiinflammatory, analgesic and hypoglycemic effects of Mangifera indica Linn. (Anacardiaceae) stem-bark aqueous extract. Methods Find Exp Clin Pharmacol. 27: 547554. https://doi.org/10.1358/mf.2005.27.8.928308

Okpanyi SN, Ezeukwu GC (1981) Anti-inflammatory and antipyretic activities of Azadirachta indica. Planta Med. 41: 34-39. https://doi.org/10.1055/s-2007-971670

Olajide OA, Aderogba MA, Adedapo AD, Makinde JM (2004) Effects of Anacardium occidentale stem bark extract on in vivo inflammatory models. J Ethnopharmacol. 95: 139-

142. https://doi.org/10.1016/j.jep.2004.06.033

Olajide OA, Aderogba MA, Fiebich BL (2013) Mechanisms of anti-inflammatory property of Anacardium occidentale stem bark: inhibition of NF-kB and MAPK signalling in the microglia. J Ethnopharmacol. 145: 42-49. https://doi.org/10.1016/j.jep.2012.10.031

Olajide OA, Awe SO, Makinde JM, Ekhelar Al, Olusola A, Morebise O, Okpako DT (2000) Studies on the anti-inflammatory, antipyretic and analgesic properties of Alstonia boonei stem bark. J Ethnopharmacol. 71: 179-186. https://doi.org/10.1016/s0378-8741(99)00200-7

Olanlokun JO, Bolaji OM, Agbedahunsi JM, Olorunsogo 00 (2012) Therapeutic effects of various solvent fractions of Alstonia boonei (apocynaceae) stem bark on Plasmodium berghei-induced malaria. Afr J Med Med Sci. 41 Suppl: 27-33.

Owuor BO, Ochanda JO, Kokwaro JO, Cheruiyot AC, Yeda RA, Okudo CA, Akala HM (2012) In vitro antiplasmodial activity of selected Luo and Kuria medicinal plants. J Ethnopharmacol. 144: 779781. https://doi.org/10.1016/j.jep.2012.09.045

Pacher P, Beckman JS, Liaudet L (2007) Nitric oxide and peroxynitrite in health and disease. Physiol Rev. 87: 315-424. https://doi.org/10.1152/physrev.00029.2006

Pooladanda V, Thatikonda S, Bale S, Pattnaik B, Sigalapalli DK, Bathini NB, Singh SB, Godugu C (2019) Nimbolide protects against endotoxin-induced acute respiratory distress syndrome by inhibiting TNF-a mediated NF-kB and HDAC-3 nuclear translocation. Cell Death Dis. 10:

81. https://doi.org/10.1038/s41419-018-1247-9

Prato M, D'Alessandro S, Van den Steen PE, Opdenakker G, Arese P, Taramelli D, Basilico N (2011) Natural haemozoin modulates matrix metalloproteinases and induces morphological changes in human 
microvascular endothelium. Cell Microbiol. 13: 1275-1285. https://doi.org/10.1111/j.1462-

5822.2011.01620.x

Shio MT, Eisenbarth SC, Savaria M, Vinet AF, Bellemare MJ, Harder KW, Sutterwala FS, Bohle DS, Descoteaux A, Flavell RA, Olivier M (2009) Malarial hemozoin activates the NLRP3 inflammasome through Lyn and Syk kinases. PLoS Pathog. 5(8):

e1000559. https://doi.org/10.1371/journal.ppat.1000559

Tripathi AK, Sha W, Shulaev V, Stins MF, Sullivan DJ Jr (2009) Plasmodium falciparum-infected erythrocytes induce NF-kappaB regulated inflammatory pathways in human cerebral endothelium. Blood 114: 4243-4252. https://doi.org/10.1182/blood-2009-06-226415

Tripathi AK, Sullivan DJ, Stins MF (2006) Plasmodium falciparum-infected erythrocytes increase intercellular adhesion molecule 1 expression on brain endothelium through NF-kappaB. Infect Immun. 74: 3262-3270. https://doi.org/10.1128/IAl.01625-05

Udeinya IJ, Brown N, Shu EN, Udeinya FI, Quakeyie I (2006) Fractions of an antimalarial neem-leaf extract have activities superior to chloroquine, and are gametocytocidal. Ann Trop Med Parasitol. 100: 1722. https://doi.org/10.1179/136485906X78508

Udeinya JI, Shu EN, Quakyi I, Ajayi FO (2008) An antimalarial neem leaf extract has both schizonticidal and gametocytocidal activities. Am J Ther. 15: 108-

110. https://doi.org/10.1097/MJT.0b013e31804c6d1d

Velagapudi R, Kosoko AM, Olajide OA (2019) Induction of neuroinflammation and neurotoxicity by synthetic hemozoin. Cell Mol Neurobiol. 39: 1187-1200. https://doi.org/10.1007/s10571-019-00713-4 WHO (2020) World Malaria Report 2020. Geneva: World Health Organization.

\section{Tables}

Table 1: Plants with $\mathrm{FL}>50 \%$ in the treatment of malaria and/or cerebral malaria by traditional medicine practitioners in some locations of southwest Nigeria 
Table 1

\begin{tabular}{|l|l|l|}
\hline Plant Name & Part used & FL (\%) \\
\hline Ageratum conyzoides & Leaves & 67 \\
\hline Alstonia boonei & Stem bark & 77 \\
\hline Anacardium occidentale & Stem bark & 87 \\
\hline Azadiractha indica & Leaves & 81 \\
\hline Chromolaena odorata & Whole plant & 79 \\
\hline Enantia chlorantha & Stem bark & 86 \\
\hline Khaya senegalensis & Stem bark & 75 \\
\hline Mangifera indica & Stem bark & 77 \\
\hline Nauclea latifolia & Stem bark & 86 \\
\hline Psidium guajava & Leaves & 78 \\
\hline Tithonia diversifolia & Leaves & 89 \\
\hline Vernonia amygdalina & Leaves & 75 \\
\hline
\end{tabular}

\section{Figures}

A

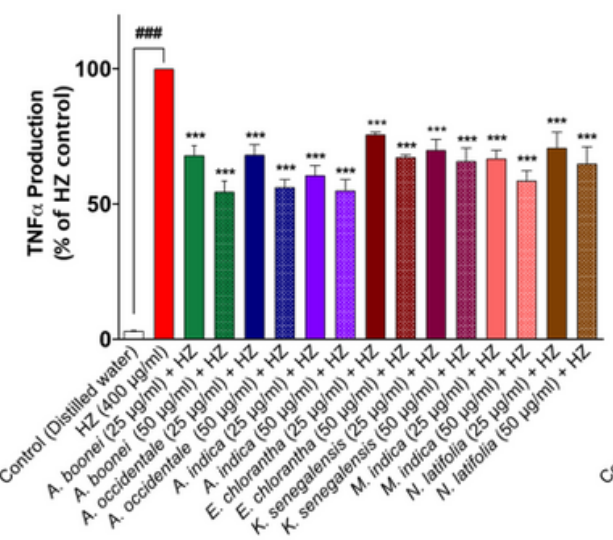

B

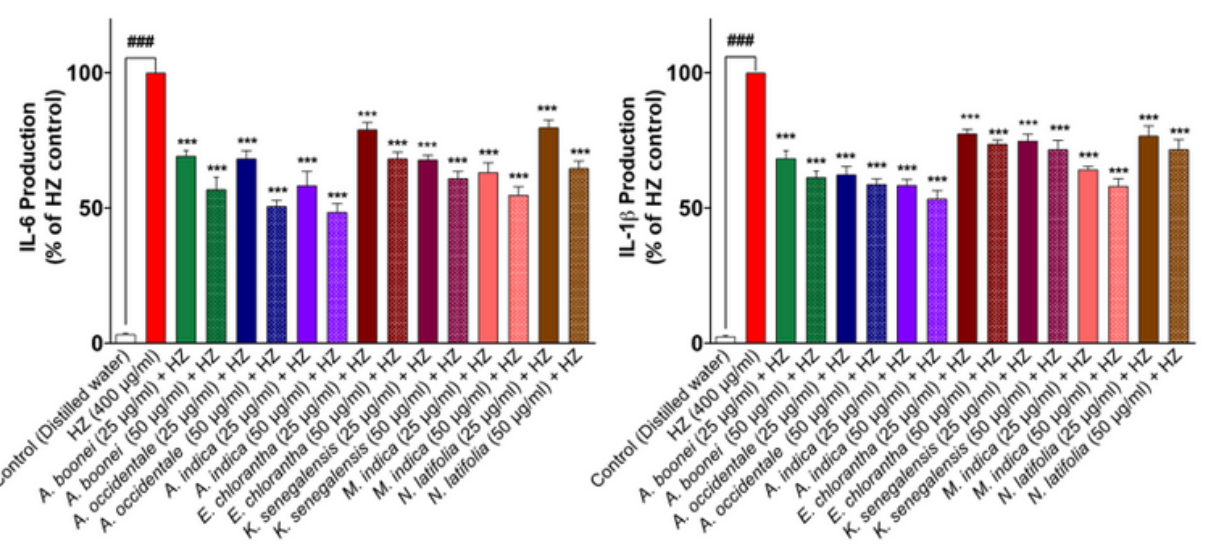


Figure 1

Effects of freeze-dried infusions of plants on increased production of TNFa (A), IL-6 (B), and IL-1 $\beta$ (C) in $\mathrm{HZ}$-stimulated BV-2 microglia. Cells were treated with 25 and $50 \mu \mathrm{g} / \mathrm{mL}$ of freeze-dried infusions prior to stimulation with $\mathrm{HZ}(400 \mu \mathrm{g} / \mathrm{mL})$ for $24 \mathrm{~h}$. Levels of cytokines were detected using mouse ELISA kits. Values are mean \pm SEM for at least 3 independent experiments (\#\#\# $p<0.001$ unstimulated control versus $\mathrm{HZ}$ stimulation. ${ }^{* \star *} \mathrm{p}<0.001$, treatments versus $\mathrm{HZ}$ stimulation; one-way ANOVA with post-hoc Dunnett's multiple comparison test).

A

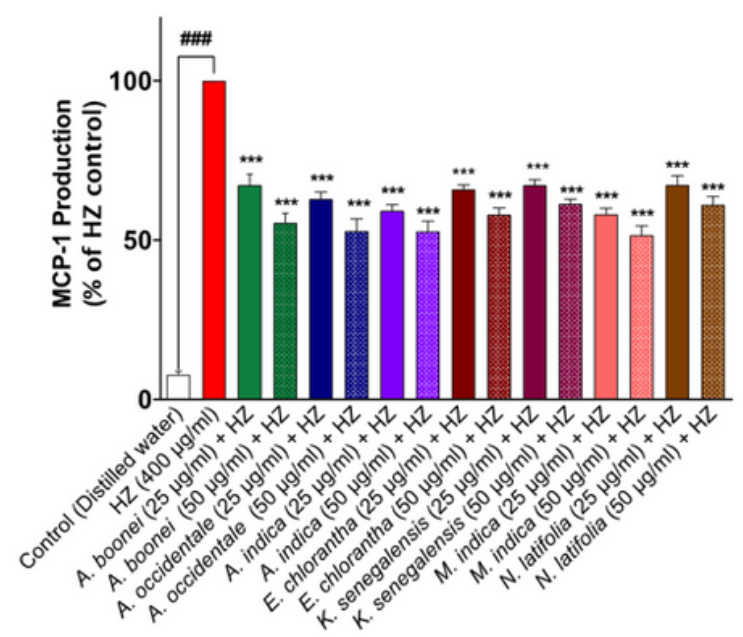

B

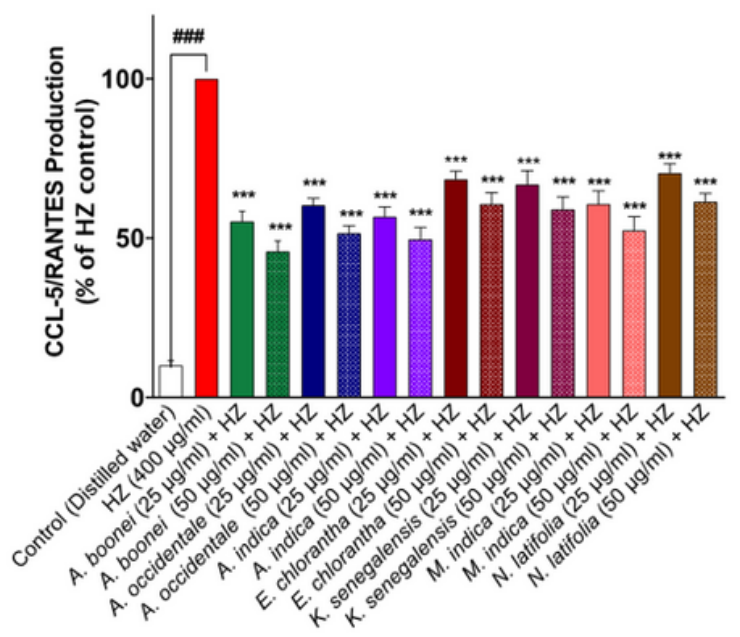

Figure 2

Effects of freeze-dried infusions of plants on increased production of MCP-1 (A) and CCL-5/RANTES (B) in HZ-stimulated BV-2 microglia. Cells were treated with 25 and $50 \mu \mathrm{g} / \mathrm{mL}$ of freeze-dried infusions prior to stimulation with $\mathrm{HZ}(400 \mu \mathrm{g} / \mathrm{mL})$ for $24 \mathrm{~h}$. Levels of chemokines were detected using mouse ELISA kits. Values are mean \pm SEM for at least 3 independent experiments (\#\#\# $p<0.001$ unstimulated control versus $\mathrm{HZ}$ stimulation. ${ }^{* \star} \mathrm{p}<0.001$, treatments versus $\mathrm{HZ}$ stimulation; one-way ANOVA with post-hoc Dunnett's multiple comparison test). 
A

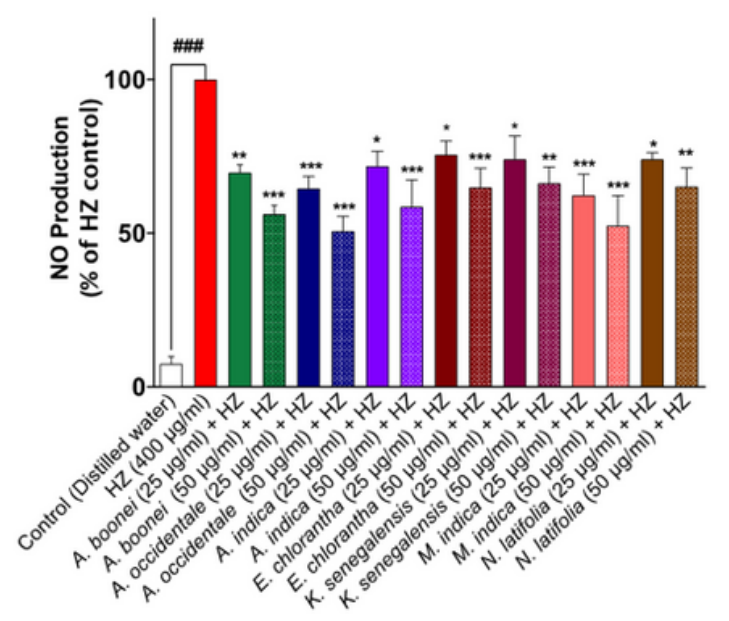

B

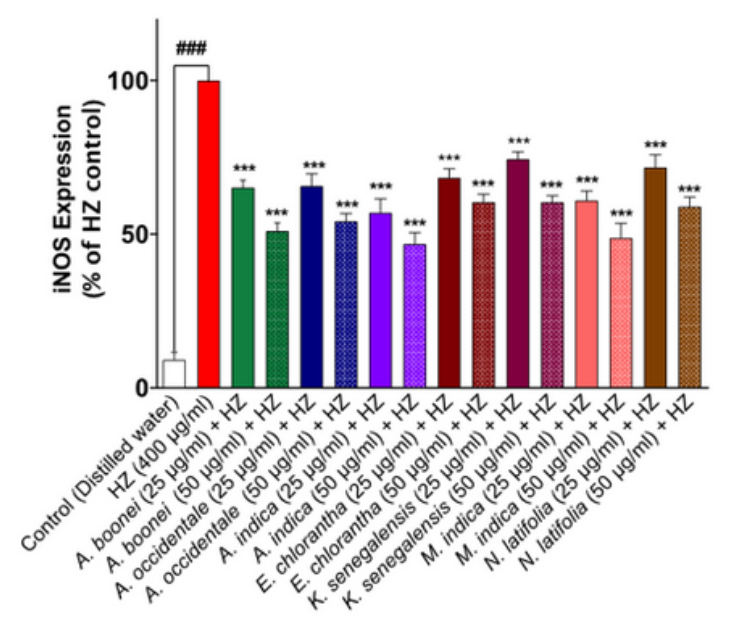

\section{Figure 3}

Effects of freeze-dried infusions of plants on increased production of NO (A) and iNOS protein expression (B) in HZ-stimulated BV-2 microglia. Cells were treated with 25 and $50 \mu \mathrm{g} / \mathrm{mL}$ of freeze-dried infusions prior to stimulation with $\mathrm{HZ}(400 \mu \mathrm{g} / \mathrm{mL})$ for $24 \mathrm{~h}$. Levels of NO were detected using the Griess assay, while iNOS protein expression was measured with in cell western ELISA. Values are mean \pm SEM for at least 3 independent experiments (\#\#\# $p<0.001$ unstimulated control versus $H Z$ stimulation. ${ }^{*}<<0.05$; ${ }^{* \star} \mathrm{p}<0.01 ;{ }^{* \star *} \mathrm{p}<0.001$, treatments versus $\mathrm{HZ}$ stimulation; one way ANOVA with post-hoc Dunnett's multiple comparison test).

A

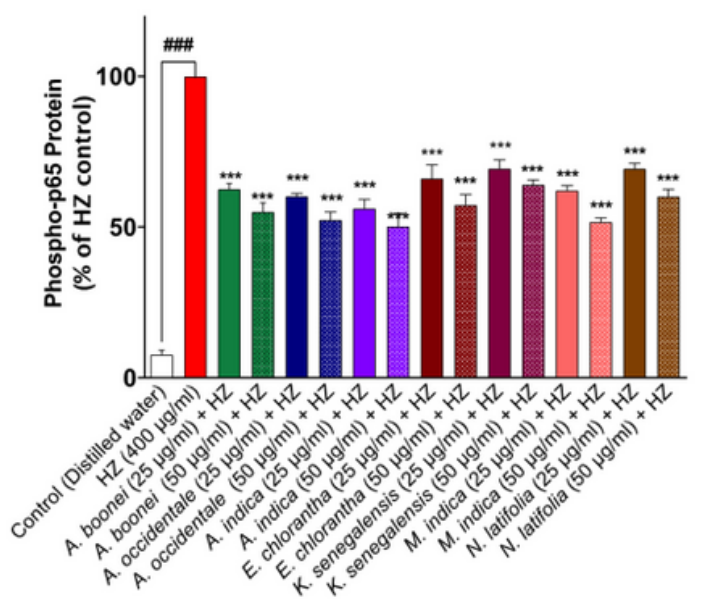

B

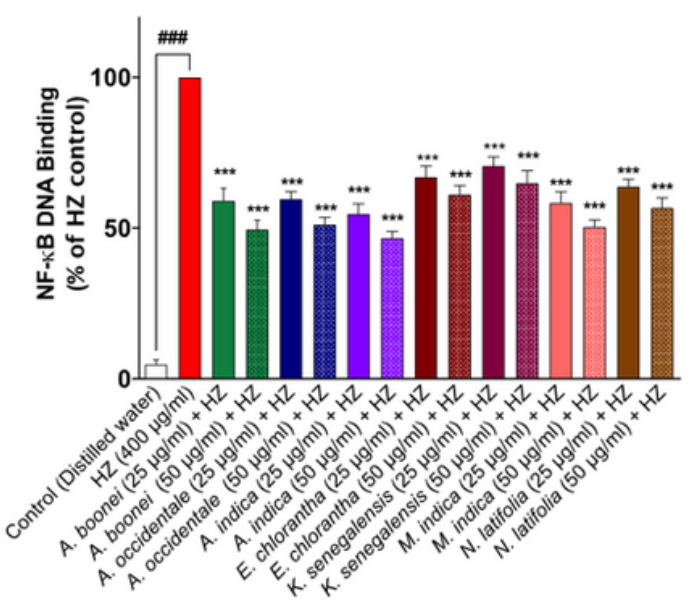

Figure 4

Effects of freeze-dried infusions of plants on increased phospho-p65 protein expression (A) and NF-KB DNA binding (B) in HZ-stimulated BV-2 microglia. Cells were treated with 25 and $50 \mu \mathrm{g} / \mathrm{mL}$ of freeze-dried 
infusions prior to stimulation with $\mathrm{HZ}(400 \mu \mathrm{g} / \mathrm{mL})$ for $60 \mathrm{~min}$. Values are mean \pm SEM for at least 3 independent experiments (\#\#\# $p<0.001$ unstimulated control versus $\mathrm{HZ}$ stimulation. ${ }^{* \star} \mathrm{p}<0.001$, treatments versus $\mathrm{HZ}$ stimulation; one way ANOVA with post-hoc Dunnett's multiple comparison test).

A

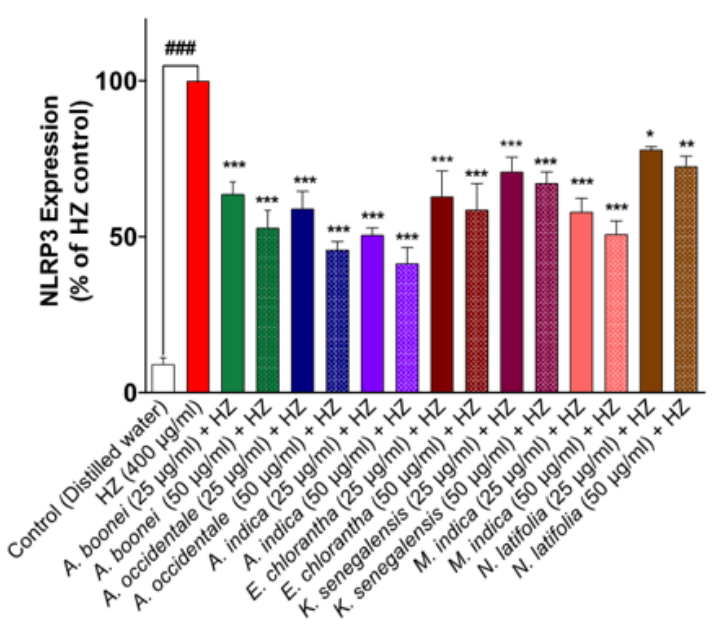

B

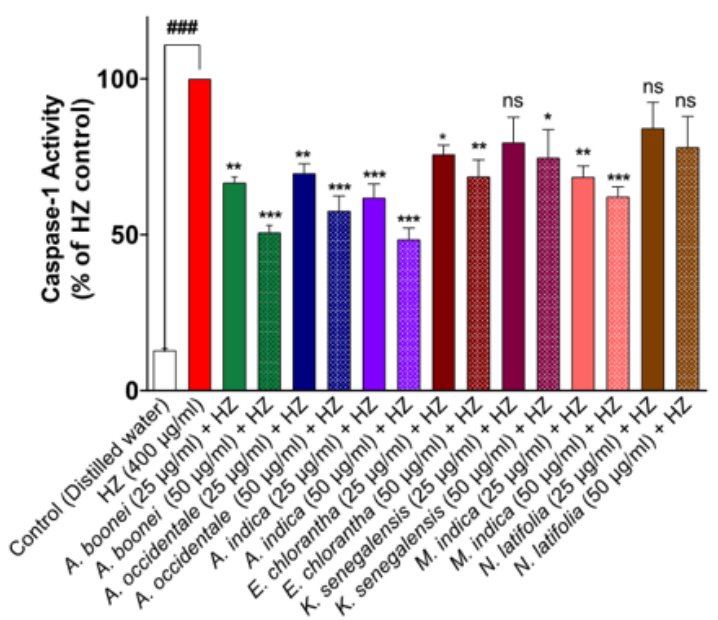

\section{Figure 5}

Effects of freeze-dried infusions of plants on increased NLRP3 protein expression (A) and caspase-1 activity (B) in HZ-stimulated BV-2 microglia. Cells were treated with 25 and $50 \mu \mathrm{g} / \mathrm{mL}$ of freeze-dried infusions prior to stimulation with $\mathrm{HZ}(400 \mu \mathrm{g} / \mathrm{mL})$ for $24 \mathrm{~h}$. Values are mean \pm SEM for at least 3 independent experiments (\#\#\# $\mathrm{p}<0.001$ unstimulated control versus $\mathrm{HZ}$ stimulation. ns (not significant); ${ }^{*} \mathrm{p}<0.05 ;{ }^{* \star} \mathrm{p}<0.01$; ${ }^{* \star} \mathrm{p}<0.001$, treatments versus $\mathrm{HZ}$ stimulation; one way ANOVA with post-hoc Dunnett's multiple comparison test).

\section{Supplementary Files}

This is a list of supplementary files associated with this preprint. Click to download.

- Supplementarydata.pptx 